\title{
KONSEP KESETARAAN GENDER DALAM PENDIDIKAN ISLAM
}

\author{
NITA KARTIKA
}

\begin{abstract}
Islam is a religion that upholds the value of justice and equality contains the principles of equality. Men and women alike as creatures of Allah, as caliphs on earth and have the potential to achieve optimal potential. Gender Equality is the main agenda of the feminism movement, since the inclusion of gender discourse in Islamic religion, some Muslim thinkers are influenced by the concept of gender, they assume that Islam that came during the time of the prophet has similarities with the concept of gender brought by feminism, finally many texts the laws and verses that have governed the relationship between men and women are reviewed to suit the perspective of gender equality. The problem is many concepts that are not in line even contrary to the concept of justice in Islam. For this reason, the concept of gender equality in Islamic religious education must be known so that there is no gender bias in education. The right of women to obtain education and achieve the same achievements as men is one of the goals of gender equality in education, but the limits taught in Islamic education also need to be considered.
\end{abstract}

Keywords: Gender, education, Islam

\section{Pendahuluan}

Islam adalah Agama Rahmatan Lil'Alamin, Allah SWT menciptakan lakilaki dan perempuan sebagai khalifah Fil Ardh, yang memiliki kewajiban yang sama dalam memakmurkan dan memelihara kelangsungan hidup manusia.

Konsep Kesetaraan gender dalam islam perlu di lihat bahwa bagaimana islam mengapresiasikan kedudukan perempuan dan kesetaraan yang di munculkannya. Diantara 114 surat yang terdapat dalam Al-Quran, terdapat satu surat yang di dedikasikan untuk perempuan secara khusus memuat hak azasi perempuan dan bagaimana aturan-aturan yang seharusnya perempuan berlaku dalam hal pernikahan, keluarga dan kehidupan. Semuanya di jelaskan dalam surat An-Nisa dan tidak satu pun surat yang khusus di tunjukan kepada laki-laki. Lebih jauh lagi islam datang pada saat revolusi yang mengeliminasi deskriminasi kaum jahiliyah atas perempuan dengan pemberian hak warisan, menegaskan bahwa adanya persamaan hak dan status dengan laki-laki. 
Pelarangan nikah dengan jaminan hukum bagi perempuan dan mengeluarkan aturan yang mengangkat derajat perempuan dan perceraian yang manusiawi.

Dalam pandangan islam, manusia mempunyai dua kapasitas, yang pertama adalah sebagai hamba ('Abid) dan sebagai Representativ Tuhan (Khalifah) tanpa membedakan jenis kelamin, etnik, warna kulit, dan lain sebagainya. Sebagaimana di jelaskan dalam (Q.S al-Hujrat[49]:13)

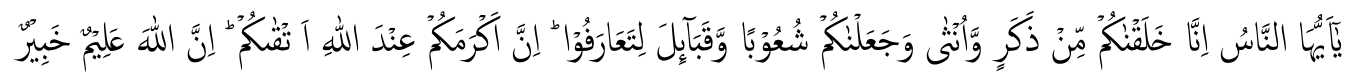

Artinya : "Hai manusia sesungguhnya kami menciptakan kamu dari seorang laki-laki dan seorang perempuan dan menjadikan kamu berbangsa-bangsa dan bersuku-suku supaya kamu saling kenal-mengenal. Sesungguhnya orang yang paling mulia diantara kamu di sisi Allah adalah orang yang paling bertakwa diantara kamu." (Q.S al-Hujrat[49]:13).

Ayat tersebut menjelaskan tentang persamaan antara laki-laki dan perempuan baik dalam dimensi spritual (ibadah) maupun dalam aktivitas sosial dalam urusan karir profesional. Ayat ini juga mengikis pandangan yang menyatakan bahwa antara laki-laki dan perempuan terdapat perbedaan yang memarginalkan salah satu diantara keduanya. persamaan tersebut meliputi berbagai hal misalnya dalam bidang ibadah. Contohnya jika seseorang yang rajin ibadah, maka akan mendapat pahala lebih banyak dibandingkan seseorang yang tidak melaksanakan ibadah, tanpa melihat jenis kelaminnya. Perbedaan ada disebabkan kualitas nilai dalam hal ketakwaannya kepada Allah swt., Ayat ini juga mempertegas misi pokok al-Qur'an diturunkan adalah untuk membebaskan manusia dari berbagai bentuk diskriminasi dan penindasan dari berbagai macam perbedaan.

\section{Metode Kajian}

Kajian ini menggunakan metode critical review (tinjauan kritis) terhadap sejumlah literatur yang relevan yang memungkinkan diperoleh perspektif kritis tentang isu gender dalam pendidikan Islam. Sejumlah literatur primer dan sekunder yang relevan ditinjau secara kritis melalui analisis isi dan analsis kritis.

\section{Hasil Kajian dan Pembahasan}

Menurut bahasa kata gender diartikan sebagai "the grouping of words into masculine, feminine, and neuter, according as they are regarded as male, female or without sex" yang artinya gender adalah kelompok kata yang mempunyai sifat maskulin, feminine, atau tanpa keduanya (netral). Dapat kita pahami bahwa gender adalah perbedaan yang bukan biologis dan bukan kodrat dari Tuhan. Konsep gender haarus kita bedakan dengan kata sex (kelamin). Perbedaan antara laki-laki dan peremuan adalah kodrat yang di berikan Tuhan yang tidak bisa kita rubah secara permanen dan merupakan 
ketentuan secara biologis. Sedangkan gender adalah suatu perbedaan tingkah laku anatara laki-laki dan perempuan yang di bentuk secara sosial dan budaya masyarakat.

Konsep gender tidak di bawa sejak lahir melainkan di bentuk dari kebiasaan sosial di lingkungan masyrakat secara sosialisasi, oleh sebab itu gender bisa berubah. Dapat kita lihat di lingkungan masyarakat tertentu, nilai dan adat kebiasaan yang mendukung atau melarang anak perempuan yang ikut serta dalam pendidikan formal, sebagai akibat ketidaksamaan kesempatan antara laki-laki dan perempuan.

Perbedaan anatara laki-laki dan perempuan karena faktor biologis misalnya, bentuk fisik, karateristik reproduksi perempuan dan laki-laki serta fungsi biologis seperti, hamil, melahirkan, menyusui, sedangkan laki-laki membuahi. Karakteristik dan fungsi jenis kelamin bersifat kodrati, universal, di dapat bersama kelahiran dan tidak bisa di pertukarkan, walapun di jaman sekarang banyak yang merubah jenis kelamin melalui jalan oprasi kelamin namun tetap saja kodratnya tidak bisa beruabah.

Gender adalah konsep atau rancangan nilai yang mengacu pada sistem hubungan sosial yang membadakan peran perempuan dan laki-laki di karenakan perbedaan biologis secara kodrti, yang di lakukan masyarakat menjadi pemikiran melekat dan menjadi sebuah hebit (kebiasaan). Sehingga muncul anggapan bahwa seluruh pekerjaan domistik di rumah hanya untuk perempuan sedangkan laki-laki tugasnya hanya bekerja mencari nafkah.

H. T. Wilson dalam Sex and Gender mengartikan gender sebagai suatu dasar untuk menentukan pengaruh faktor budaya dan kehidupan kolektif dalam membedakan laki-laki dan perempuan. Agak sejalan dengan pendapat yang dikutip Showalter yang mengartikan gender lebih dari sekedar pembedaan laki-laki dan perempuan dilihat dari konstruksi sosial budaya, tetapi menekankan gender sebagai konsep analisa yang kita dapat menggunakannya untuk menjelaskan sesuatu (Gender is an analityc concept whose meanings we work to elucidate, and a subject matter we proceed to study as we try to define it). (Wilson, 1989:2)

Gender pada hakikatnya lebih menekankan aspek sosial, budaya, psikologis, dan aspek non biologis lainnya. Hal ini berarti bahwa gender lebih menekankan aspek maskulinitas atau feminitas seseorang dalam budaya tertentu. Dengan demikian, perbedaan gender pada dasarnya merupakan konstruksi yang dibentuk, disosialisasikan, diperkuat, bahkan dilegitimasi secara sosial dan budaya. Pada gilirannya, perbedaan gender dianggap kodrati hingga melahirkan ketidakseimbangan perlakuan jenis kelamin.

Nilai-nilai kesetaraan dalam islam mengandung konsep keseimbangan, keadilan, menolak ketidakadilan, keselarasan, keserasian dan keutuhan bagi manusia. Islam memaknai adil sebagai sesuatu yang proposional, sesuai dengan ukuran dan tempatnya. Bukan sama banyak atau sama rata. 
Ajaran Islam dalam memperkenalkan konsep gender mengacu pada ayat-ayat al-Quran yang menjadi tujuan umum syari'ah mewujudkan keadilan dan kebajikan. (Q.S an-Nahl :90) yang artinya :

"Sesungguhnya Allah menyuruh (kamu) berlaku adil dan berbuat kebajikan, memberi kepada kaum kerabat, dan allah melarang dari perbuatan keji, kemungkaran dan permusuhan dia memberi pengajaran kepadamu agar kamu dapat mengambil pelajaran"

Sebagai seorang khalifah, laki-laki dan perempuan mempunyai hak dan kewajiban yang sama dalam menjalankan perannya sebagai seorang hamba. Dalam al-Quran dan hadist tidak di temukan ayat al-Quran yang melarang kaum perempuan aktif dalam peran sosial di masyarakat. Sebaliknya al-Quran dan hadits banyak mengisyaratkan kebolehan perempuan aktif menekuni berbagai profesi.

Nasaruddin Umar berpendapat, ada beberapa konsep yang menunjukan bahwa prinsip-prinsip kesetaraan gender ada dalam al-Quran yaitu :

a) Perempuan dan Laki-laki sama-sama sebagai hamba

Tidak ada perbedaan antara laki-laki dan perempuan dalam kapasitasnya sebagai seorang hamba, keduanya mempunyai peluang dan potensi yang sama menjadi seseorang yang bertaqwa (Mutaqqin) sesuai dengan Q.S alZariyat (51:56).

b) Perempuan dan Laki-laki sebagai seorang khalifah di Bumi

Kata Khalifah tidak menunjukan pada salah satu jenis kelamin tertentu, artinya baik laki-laki ataupun perempuan mempunyai peran yang sama sebagai seorang khalifah, di tegaskan juga dalam Q.S al-An'am (6:165), dan dalam Q.S al-Baqarah (2:30). Dalam kedua ayat tersebut terdapat kata "khalifah" yang akan mempertangunggjawabkan tugas-tugas kekalifahannya di bumi.

c) Laki-laki dan perempuan menerima perjanjian awal dengan Tuhan Mengemban amanah dan menerima perjanjian dengan Tuhan, Seperti Q.S al-Araf (7:172) yakni Ikrar akan keberadaan Tuhan yang di saksikan oleh para malaikat. Dalam islam tidak adanya diskriminasi jenis kelamin. Lakilaki dan perempuan sama-sama mengikrarkan kesaksiannya kepada Tuhan. Quran juga menegaskan bahwa Allah memuliakan seluruh anak cucu adam tanpa membedakan jenis kelamin. (Q.S. al-Isra, 17:70)

d) Perempuan dan Laki-laki Sama-sama Berpotensi Meraih Prestasi

Peluang untuk meraih prestasi maksimum tidak ada pembedaan antara perempuan dan laki-laki ditegaskan secara khusus dalam 3 (tiga) ayat, yakni: Q.S an-Nisa/4:124; Q.S an-Nahl/16:97 dan ditegaskan secara khusus dalam QS. Ali-Imran: 195 artinya sebagai berikut:

Maka Tuhan mereka memperkenankan permohonannya (dengan berfirman): "Sesungguhnya Aku tidak menyia-nyiakan amal orang- orang yang beramal di antara kamu, baik laki-laki atau perempuan, (karena) sebagian kamu adalah turunan dari sebagian yang lain. Maka orang-orang 
yang berhijrah, yang diusir dari kampung halamannya, yang disakiti pada jalan-Ku, yang berperang dan yang dibunuh, pastilah akan Ku-hapuskan kesalahan-kesalahan mereka dan pastilah Aku masukkan mereka ke dalam surga yang mengalir sungai-sungai di bawahnya, sebagai pahala di sisi Allah. Dan Allah pada sisi-Nya pahala yang baik.

Ayat tersebut mengisyaratkan konsep kesetaraan gender yang ideal dan memberikan ketegasan bahwa prestasi individual, baik dalam bidang spiritual maupun urusan karier profesional, tidak mesti dimonopoli oleh salah satu jenis kelamin saja. Laki-laki dan perempuan berpeluang memperoleh kesempatan yang sama meraih prestasi optimal. Namun, dalam kenyataannya di masyarakat, konsep ideal ini membutuhkan tahapan dan sosialisasi, karena masih terdapat sejumlah kendala, terutama kendala budaya yang sulit diselesaikan.

e) Adam dan Hawa Terlibat secara Aktif dalam Drama Kosmis Semua ayat yang menceritakan tentang drama kosmis, yakni cerita tentang keadaan Adam dan Hawa di surga sampai keluar bumi, selalu menekankan keterlibatan keduanya secara aktif, dengan penggunaan kata ganti untuk dua orang (huma), yakni kata ganti untuk Adam dan Hawa, yang terlihat dalam beberapa kasus sebagai berikut:

1) Kaduanya diciptakan di surga memanfaatkan fasilitas surga (Q.S alBaqarah/2:35)

"Dan Kami berfirman: "Hai Adam, diamilah oleh kamu dan isterimu surga ini, dan makanlah makanan-makanannya yang banyak lagi baik dimana saja yang kamu sukai, dan janganlah kamu dekati pohon ini, yang menyebabkan kamu termasuk orang-orang yang zalim."

2) Keduanya mendapat kualitas godaan yang sama dari setan (Q.S alA'raf/7:20)

"Maka syaitan membisikkan pikiran jahat kepada keduanya untuk menampakkan kepada keduanya apa yang tertutup dari mereka yaitu auratnya dan syaitan berkata: "Tuhan kamu tidak melarangmu dan mendekati pohon ini, melainkan supaya kamu berdua tidak menjadi malaikat atau tidak menjadi orang-orang yang kekal (dalam surga)."

3) Sama-sama memohon ampun dan sama-sama diampuni Tuhan (Q.S alA'raf/7:23)

Keduanya berkata: "Ya Tuhan kami, kami telah menganiaya diri kami sendiri, dan jika Engkau tidak mengampuni kami dan memberi rahmat kepada kami, niscaya pastilah kami termasuk orang-orang yang merugi.

4) Sama-sama memakan buah khuldi dan keduanya menerima akibat jatuh ke bumi, disebutkan dalam QS. al-A'raf: 22 artinya sebagai berikut:

Maka syaitan membujuk keduanya (untuk memakan buah itu) dengan tipu daya.Tatkala keduanya telah merasai buah kayu itu, nampaklah bagi keduanya aurat-auratnya, dan mulailah keduanya menutupinya 
dengan daun-daun surga. Kemudian Tuhan mereka menyeru mereka: "Bukankah Aku telah melarang kamu berdua dari pohon kayu itu dan Aku katakan kepadamu: "Sesungguhnya syaitan itu adalah musuh yang nyata bagi kamu berdua?

5) Setelah di bumi keduanya mengembangkan keturunan salaing melengkapi dan saling membutuhkan (Q.S al-Baqarah/2:187).

Perspektif gender dalam al-Qur'an tidak sekedar mengatur keserasian relasi gender, hubungan laki-laki dan perempuan dalam masyarakat, tetapi lebih dari itu al-Qur'an juga mengatur keserasian pola relasi antara mikrokosmos (manusia), makrokosmos (alam), dan Tuhan. Konsep berpasangpasangan (azwâjj) dalam al-Qur'an tidak saja menyangkut manusia melainkan juga binatang QS. al-Syura: 11, dan tumbuh-tumbuhan QS. Thaha: 53. Bahkan kalangan sufi menganggap makhluk-makhluk juga berpasang-pasangan. Langit diumpamakan dengan suami yang menyimpan air QS. al-Thariq: 11 dan bumi diumpamakan isteri yang menerima limpahan air yang nantinya melahirkan janin atau berbagai tumbuh-tumbuhan QS. al-Thariq: 12. Satusatunya yang tidak mempunyai pasangan ialah Sang Khaliq Yang Maha Esa QS. al-Ikhlas: 14.

Secara umum tampaknya al-Qur'an mengakui adanya perbedaan (distinction) antara laki-laki dan perempuan, tetapi perbedaan tersebut bukanlah pembedaan (discrimination) yang menguntungkan satu pihak dan merugikan yang lainnya. Perbedaan tersebut dimaksudkan untuk mendukung obsesi al-Qur'an, yaitu terciptanya hubungan harmonis yang didasari rasa kasih sayang (mawaddah wa rahmah) di lingkungan keluarga QS. al-Rum: 21, sebagai cikal bakal terwujudnya komunitas ideal dalam suatu negeri damai penuh ampunan Tuhan (baldatunThayyibatun wa rabbun ghafûr) QS. Saba: 15.

\section{Peran Perempuan dalam Pendidikan Islam}

Di era moderen ini banyak sekali perbincangan tentang persamaan gender. Secara realitas peran perempuan kini menunjukan kemajuan dalam prespektif persamaan antara hak dan kedudukan dalam pendidikan. Hal ini tidak terlepas adanya kesadaran dari kaum perempuan yang meanggap bahwa pendidikan sangat penting bagi masa depan umat manusia khususnya perempuan muslim, dalam menghadapi persaingan kerja dan kair yang setara dengan laki-laki.

Sejarah telah mencatat bahwa peran perempuan dalam bidang pendidikan telah di contohkan istri Rasulullah SAW, Seperti peranan Siti Aisyah RA, yang terkenal dengan kecerdasannya dan jasanya dalam meriwayatkan beberapa hadits. Kemudian pada masa Dinasti Fatimiyyah di Mesir, yang merepresentasikan kekuatan politis representasi gender dalam politik Islam. Dinasti ini tercatat sebagai Dinasti yang mengembangkan kajian KeIslaman madzhab Syiah di Mesir dengan mendirikan Jami' al-Azhar sebagai 
cikal bakal Universitas Al-Azhar menjadi pusat pengembangan pendidikan dan keilmuan pada masanya.

Azyumardi Azra mensinyalir bahwa perhatian ulama tentang peran penting perempuan Islam dalam bidang pendidikan dan keilmuan Islam telah digambarkan secara menarik oleh beberapa ulama terkenal. Sebagaimana yang ditulis oleh sejarawan Muslim, al-Khatib al-Baghdadi dalam kamus biografinya berjudul Tarikh Baghdad, memuat biografi sejumlah ulama perempuan. Begitu juga al-Sakhawi menulis beberapa kamus biografi tokohtokoh abad ke-15 terutama al-Daw' al-Lami', khusus tentang perempuan yang diberi judul Kitab al-Nisa' . Dalam terakhir diberikan biografi sekitar 1075 perempuan, 411 orang diantaranya mempunyai pendidikan agama yang tinggi. 20 Bahkan Salabi memberikan data tentang jumlah ulama perempuan yang mencapai 1543 dalam kitan al-Ishabah fi Tamyiz al-Shahabah karya Ibnu Hajar. Begitu dalam kitab Tahzib.

Di jaman sekarang banyak juga perempuan-perempuan yang menjadi seorang hafidzah mengajarkan anak-anak didiknya dalam memahami dan menghapal al-quran. Bahkan sudah menjadi tren bahwa seorang ibu mengantarkan anak-anaknya mengikuti pelatihan, pendidikan untuk menghapal al-quran dan aktif berperan serta dalam ajang perlombaan, pencarian bakat, bahkan menjadi sebuah prestasi seorang ibu yang mendidik anak-anaknya menjadi penghapal quran.

Begitu banyak contoh-contoh lain yang di perankan seorang perempuan dalam memperoleh persamaan hak nya memperoleh pendidikan dan aktif dalam bidang sosial lainnya.

\section{Islam tentang Kedudukan Laki-laki dan Perempuan}

Agama adalah sebuah pegangan hidup bagi orang yang beriman yang paling fundamental. Pengaruhnya berfungsi terhadap struktur sosial masyarakat. Agama dijadikan alat legitimasi terhadap struktur sosial yang hanya berlaku dalam lingkungan masyarakat tersebut. Termasuk stuktur sosial yang melahirkan ketidak adilan terhadap perempuan adalah salah satunya.

Tidak dapat dipungkiri bahwa peran agama sangat berprngaruh karena pola teks-teks tafsir yang di dukung oleh legitimasi theologis (pembenaran ajaran agama) sehingga dapat di pastikan bahwa tradisi yang muncul di dalam masyarakat adalah budaya patriarkhi, dan menjadi dogma yang di anut dan di ikuti oleh masyarakat secara turun temurun. Sehingga menjadikan perempuan sebagai objek yang terdiskriminasi bahkan tereksploitasi secara politik, budaya, sosial maupun ekonomi.

Menurut sebagian besar tradisi agama, perempuan diberi peran sekunder dan subordinat. Tetapi dalam tiga dasawarsa terakhir sebagian besar tradisi agama menarik sarjana feminis yang berpendapat bahwa bukan teks agama yang menjadi sebab masalah melainkan penafsirannya. Kaum 
feminis Kristen, Yahudi dan Islam meneliti kembali ayat suci mereka dan tiba pada kesimpulan bahwa agamanya menawarkan kemungkinan pembebasan dan perbaikan dalam posisi perempuan. Tetapi tradisi dan sejarah telah menumbangkan potensi ini dan menggunakan agama untuk menekan perempuan.

Dengan adanya ajaran agama Islam, posisi perempuan secara radikal terdefinisikan kembali. Islam melarang praktek penguburan bayi wanita dan memperbaiki hak-hak kelahiran wanita. Keadilan menurut Islam adalah terpenuhinya hak bagi yang memiliki secara sah, yang jika dilihat dari sudut pandang orang lain adalah kewajiban. Oleh karena itu, siapapun yang lebih banyak melakukan kewajiban atau yang memikul kewajiban lebih besar, dialah yang memiliki hak dibanding yang lain. Sementara ini, banyak anggapan bahwa beban suami atau beban produksi untuk mencari nafkah lebih berat dari beban istri (beban reproduksi: mengandung, melahirkan dan menyusui). Oleh karena tidak ada yang dapat dikatakan lebih berbobot antara hak dan kewajibannya, tetapi seimbang dan sejajar.

Dalam hal ini Al-Qur'an sebagai kitab suci umat Islam dengan tegas menyatakan bahwa kaum perempuan memiliki hak yang sama dengan kaum laki-laki. Sebagaimana laki-laki memiliki hak atas perempuan, perempuan memiliki hak atas kaum laki-laki. Sebagaimana perempuan memiliki kewajiban terhadap laki-laki, laki-lakipun memiliki kewajiban terhadap perempuan. Karena itu, Islam mengangkat mereka ke status yang layak sebagai manusia yang bermartabat sebagaimana laki-laki. Untuk selanjutnya laki-laki dan wanita dipandang sejajar dari segi kemanusiaannya. Alqur'an menyatakan:

"Hai manusia, sesungguhnya Kami menciptakan kamu dari seorang lakilaki dan seorang perempuan dan menjadikan kamu berbangsa-bangsa dan bersuku-suku supaya kamu saling kenal mengenal. Sesungguhnya orang yang paling mulia diantara kamu disisi Allah ialah orang yang paling bertaqwa diantara kamu. Sesungguhnya Allah Maha Mengetahui lagi Maha Mengenal. (Al-Hujurat: 13

Dalam hal kepemimpinan, Al-Qur'an menjelaskan bahwa perempuan dan laki-laki memiliki hak yang sama untuk menjadi pemimpin. Salah satu kisah yang sangat terkenal dalam Al-Qur'an adalah tentang seorang ratu (AlQur'an, an- Naml ayat 22-23) yang digambarkan sebagai seorang perempuan yang menggunakan kekuasaan dengan sebaik-baiknya untuk membimbing rakyatnya agar patuh pada nabi Sulaiman. Ia adalah Ratu Saba', yang menjadi model peranan amat positif dari seorang perempuan yang menjadi kepala negara.

Sejarah kepemimpinan Aisyah - istri Nabi Muhammad SAW - dalam dunia politik ikut memperkuat maksud dibalik cerita tentang Ratu saba' di atas. Puncak kepemimpinan Aisyah adalah ketika dalam perang jamal beliau memimpin sendiri pasukannya melawan Ali bin Abi Thalib, yang tiada lain 
adalah menantunya sendiri. Meskipun pada akhirnya ia dan pasukannya dikalahkan, tetapi ia berhasil menunjukkan pada umat bahwa seorang perempuan bisa menjadi pemimpin masyarakat.

Perempuan yang bekerja, baik dalam lapangan ekonomi maupun sosial seperti halnya laki-laki - menurut ajaran Islam, sebenarnya tidakalah menjadi masalah. Dalam Al-Qur'an, Hadits, maupun Fiqh - yang merupakan sumber ajaran Islam - tidak satupun ada penjelasan yang menafikan kerja dan profesi perempuan dalam segala sektor kehidupan, baik untuk kepentingan pribadi maupun kepentingan sosial.25 Peluang perempuan dalam mendapat pendidikan, terlalu banyak ayat al Qur'an dan hadits Nabi Saw. Yang berbicara tentang kewajiban belajar, baik kewajiban tersebut ditujukan kepada lelaki maupun perempuan. Wahyu pertama dari al Qur'an adalah perintah membaca atau belajar:

Para perempuan di zaman Rasul menyadari betul kewajiban ini, sehingga mereka memohon kepada Rasul Saw. Agar beliau bersedia menyisihkan waktu tertentu dan khusus untuk mereka dalam rangka menuntut ilmu pengetahuan. Permohonan tersebut tentu dikabulkan oleh Rasul SAW. Al Qur'an memberikan pujian kepada para Ulul Al Albab (intelektual) yang selalu berdzikir dan berfikir sekaligus memikirkan tentang telah diciptakannya langit dan bumi, pergantiannya siang dan malam, perputarannya matahari dan rembulan yang selalu aktif dan hanyalah Allah SWT. Yang Maha Pencipta. Dzikir dan pemikiran menyangkut hal tersebut akan mengantar manusia untuk mengetahui rahasia-rahasia alam raya, dan hal tersebut tidak lain dari pengetahuan.

Ini berarti bahwa kaum perempuan dapat berfikir, mempelajari dan kemudian mengamalkan apa yang mereka hayati dari dzikir kepada Allah Swt. serta apa yang mereka ketahui dari alam ini. pengetahuan menyangkut alam raya tentunya berkaitan dengan berbagai disiplin ilmu, sehingga dari ayat ini dapat dipahami bahwa perempuan bebeas untuk mempelajarti apa saja, sesuai dengan keinginan dan kecenderungan masing-masing.27 Dalam kehidupan berkeluarga, tidak ada satupun penjelasan dalam Al-Qur'an yang menyatakan bahwa status laki-laki lebih tinggi dari perempuan. Seorang suami tidak lebih dominan dibanding istri. Demikian juga anak laki-laki tidak lebih utama dari anak perempuan. Memang ada sebuah penjelasan dalam AlQur'an tentang hubungan suami-istri yang tertulis pada surat an-Nisa' ayat 34, yang sebetulnya penuh dengan berbagai penafsiran.

Ayat yang menyatakan bahwa laki-laki (suami) adalah "pemimpin" bagi perempuan (istri) ini adalah bersifat kontekstual, dan bukan normatif.28 Artinya, ayat ini diturunkan berkaitan dengan konteks masyarakat pada saat itu. Kondisi masyarakat saat itu sangat diwarnai oleh budaya patriarkhi. Bila dipahami lebih jauh, ayat tersebut menggambarkan bahwa waktu itu laki-laki (suami) menjadi pemimpin bagi perempuan (istri) disebabkan kelebihan yang dimiliki laki-laki dan karena laki-laki yang memberi nafkah pada perempuan. 
Ayat tersebut tidak berlaku secara normatif, dalam arti untuk semua tempat dan waktu. Segala hal yang berkaitan dengan kehidupan berkeluarga adalah tanggung jawab suami-istri secara bersama-sama untuk mengaturnya. Subhan, menggambarkan, hidup berkeluarga itu ibarat seekor burung yang sedang terbang dengan kedua sayapnya. Kedua sayap itu bagaikan suami-istri. Bila salah satu sayap itu tidak berfungsi maka burung itu tidak bisa terbang.

Dengan demikian, Al-Qur'an yang merupakan kitab suci pemeluk agama Islam, sebenarnya menganugerahkan status yang setara antara laki-laki dan perempuan dalam pengertian normatif, namun juga mengakui superioritas laki-laki dalam konteks sosial tertentu. Namun para teolog yang menafsirkan ajaran Al-Qur'an tersebut telah mengabaikan konteks sosial yang dimaksud, sehingga menjadikan laki-laki sebagai makhluk superior. Pemahaman seperti ini kemudian mewarnai berbagai penafsiran terhadap ajaran yang terkait dengan hubungan laki-laki dan perempuan dalam kitab suci tersebut.31 Dengan bahasa yang berbeda, Engineer, mengungkapkan bahwa kitab suci AlQur'an itu bersifat normatif sekaligus pragmatis. Ajaran-ajarannya memiliki relevansi dengan zaman sekarang. Ajaran-ajaran yang demikian seharusnya tidak diperlakukan sebagai ajaran yang normatif. Ajaran ini harus dilihat dalam konteks di mana ajaran tersebut harus diterapkan.

Jika demikian, pemahaman keagamaan yang ada selama ini memberikan andil yang tidak kecil terhadap pelanggaran ide normatif Islam itu sendiri. Oleh karena itu jelas diperlukan kerendahan hati untuk mencermati ulang penafsiran yang dirasakan tidak mampu menjaga hak-hak kaum perempuan. Maka, diperlukan kajian kritis guna mengakhiri bias dan dominasi dalam penafsiran agama. Maka diperlukan suatu proses kolektif yang mengkombinasikan studi, investigasi, analisis sosial, pendidikan, serta aksi untuk membahas issu perempuan. Hal ini termasuk memberikan semangat dan kesempatan perlawanan kepada kaum perempuan guna mengembangkan tafsiran ajaran agama yang tidak bias laki-laki.

\section{Kesimpulan}

Gender adalah suatu konsep yang digunakan untuk mengidentifikasi perbedaan laki-laki dan perempuan dilihat dari segi pengaruh sosial budaya. Gender dalam arti ini adalah suatu bentuk rekayasa masyarakat (social constructions), bukannya sesuatu yang bersifat kodrati. Antara gender dan sex sangat berbeda, secara umum dapat dikatakan bahwa gender digunakan untuk mengidentifikasi perbedaan laki-laki dan perempuan dan lebih banyak berkonsentrasi kepada aspek sosial, budaya, psikologis, dan aspek-aspek non biologis lainnya, maka sex secara umum digunakan untuk mengidentifikasi perbedaan laki-laki dan perempuan dari segi anatomi biologi.

Terakhir yang perlu dipahami adalah konsep gender pada Al-Qur'an tidak mengajarkan diskriminasi antara laki-laki dengan perempuan sebagai manusia. Dihadapan Allah SWT lelaki dan perempuan mempunyai derajat dan 
kedudukan yang sama. Oleh karena itu pandangan-pandangan yang menyudutkan posisi perempuan sudah selayaknya diubah, karena Qur'an menyerukan keadilan (Q.S an-Nahl/16:90); keamanan dan ketentraman (Q.S an-Nisa/4:58); mengutamakan kebaikan dan mencegah kejahatan (Q.S Ali Imran/3:104). Ayat-ayat inilah yang dijadikan tujuan-tujuan utama dari agama sebagai Rihmatan Lil 'Alamin.

\section{DAFTAR PUSTAKA}

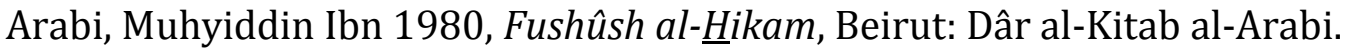

Departemen Agama RI, 1992, Al-Qur'an terjemahan Departemen Agama Bandung: Gema Insani Press.

Echols, John M. dan Hassan Shadily, 1983, Kamus Inggeris Indonesia, Cet. I; Jakarta: Gramedia, cet. XII.

Fakih, Mansur 1996, Analisis Gender dan Transformasi Sosial.Cet. I; Yogyakarta: Pustaka Pelajar.

H.T. Wilson, Sex and Gender, Making Cultural Sense of Civilization (Leiden, New York, Kobenhavn, Koln: EJ. Brill, 1989), h. 2.

Illich, Ivan. 2001, Matinya Gender.Cet. III, Yogyakarta: Pustaka Belajar.

al- Ishfahani, Mu'jam Mufradat al-fazdh al-Qur'an Beirut: Dâr al-Fikr, t.th

Lane, E.W. 1984, Arabic English Lexicon, Cambridge: The Islamic Texts Society.

Lindsey, Linda L. 1990, Gender Roles a Sociological Perspective, New Jersey: Prentice Hall.

Lips, Hilary M. 1993, Sex \& Gender an Introduction, California, London, Toronto: Mayfield Publishing Company.

Muin, H. Abd. 1992, Fiqih Siyasah; Konsepsi Kekuasaan Politik dalam Al-Qur'an Cet. I; Jakarta: PT. RajaGrafindo Persada.

Neufeldt, Victoria (ed.), 1984, Webster's New World Dictionary,New York: Webster's New World Cleveland.

Pickthall, Marmaduke. 1958, The Meaning of the Glorious Koran, New York: A Amentor Religious Classic,.

Redaksi Pustaka Tinta Mas, Undang-undang Perkawinan.UU No. 1/1974, PP No. 9/1975 dan PP No. 10/1983, Pustaka Tinta Mas, Surabaya, 1986.

Shihab, Umar. 1996, Hukum Islam dan Transformasi Pemikiran.Cet.I; Semarang: Dina Utama.

Showalter (Ed.), Elaine, 1989, Speaking of Gender, New York \& London: Routledge.

Tierney (Ed.), Helen Women's Studies Encyclopedia, Vol. I, NewYork: Green Wood Press.

Umar, Nasaruddin 1999, Argumen Kesetaraan Gender perspektif al-Qur'an.Cet. I; Jakarta: Paramadina. 
Wilson, H.T. 1989, Sex and Gender, Making Cultural Sense of Civilization, Leiden, New York, Kobenhavn, Koln: EJ. Brill.

Umar, Nasruddin. 1997. Analisis gender dalam Islam: Alternatif Menuju Transformasi Sosial. Bandung: Mizan 